\title{
NIZHAMIYAH
}

JurnalPendidikanIslamdanTeknologiPendidikan

Vol. VIII,No1,Januari- Juni 2018

ISSN2086-4205

\section{UPAYA MENINGKATKAN KEMAMPUAN BERBICARASISWA MELALUI TEKNIK BERCERITABERPASANGAN DI KELAS IIISD NEGERI 060954 MEDAN}

\author{
ULFAH SARI REZEKI \\ Dosen Tetap FKIP UNIV.QUALITY \\ Email : ulfahsari6@gmail.com
}

\begin{abstract}
Abstrak: Penelitian bertujuan untuk peningkatan kemampuan berbicara siswa melalui teknik bercerita berpasangan terhadap kelas III SD Negeri 060954 Medan. Lokasi penelitian di SD Negeri 060954 Medan dan Subjek penelitian ini adalah siswa kelas III SD Negeri 060954 Medan. Siswa yang hadir pada Siklus I dan Siklus II sebanyak 24 siswa.

Teknik yang digunakan dalam penelitian ini adalah teknik bercerita berpasangan yaitu untuk mengetahui kemampuan berbicara siswa. Alat pengumpulan data adalah tes lisan dalam bentuk menceritakan peristiwa yang dialami siswa. Hasil belajar dengan menggunakan teknik pembelajaran bercerita berpasangan berada dalam kategori baik dengan nilai rata-rata meningkat, ketuntasan belajar siswa, tuntas secara individual dan klasikal.

Nilai individu pada Siklus I masih rendah namun setelah dilakukan perbaikan pada Siklus II setiap nilai individual meningkat, nilai rata-rata pada Siklus I yaitu 70 setelah dilakukan perbaikan pada Siklus II meningkat menjadi 80, dan Ketuntasan klasikal pada Siklus I mencapai $54,16 \%$ dalam kategori cukup namun setelah dilakukan perbaikan pada Siklus II mengalami peningkatan $87,5 \%$.

Berdasarkan hasil penelitian ini, dapat disimpulkan bahwa pelaksanaan pembelajaraan dengan menggunakan teknik bercerita berpasangan dengan mata pelajaran Bahasa Indonesia pada materi Peristiwa di Kelas III SD Negeri 060954 Medan sudah berkategori baik dan hasil belajar siswa meningkat.
\end{abstract}

Kata kunci: Teknik, Peningkatan, Kemampuan, Teknik bercerita berpasangan, Bahasa Indonesia.

Abstract: The study aims to describe the students' speaking abilities through storytelling techniques paired against class III Private SD Negeri 060954 Medan. The location of research in private SD Negeri 060954 Medan and the research subject is class III Private SD Negeri 060954 Medan. Students who attend at Cycle I and Cycle II as many as 24 students.

The technique used in this study were paired storytelling techniques is to determine the students, speaking ability. Data collection tool is an oral test in the form tells the events experienced by students. Learning outcomes using the technique of storytelling pairs are learning in both categories with an average value increase, mastery learning students, completed individually and classical.

The value of the individual in Cycle I are still low but after the improvement in Cycle II each individual value increases, the average value in the first cycle of 70 after repairs in Cycle II increased to 80, and completeness classical in Cycle I reach 54,16\%in category enough but after the improvement in Cycle II increased $87.5 \%$. 


\section{NIZHAMIYAH}

JurnalPendidikanIslamdanTeknologiPendidikan

Vol. VIII,No1,Januari- Juni 2018

ISSN2086-4205

Based on the result of this study, it can be concluded that the implementation of learning using storytelling 2echniques paired with Indonesian subject on the material events in the class III Private SD Negeri 060954 Medanhave been categorized in class is good and has improved learning outcomes.

Keywords: Tecnique, Improvement, Capability, Storytelling techniques in pairs, Indonesian language.

\section{A. PENDAHULUAN}

Dalam kurikulum pendidikan sekolah dasar berdasarkan kurikulum tingkat satuan pendidikan (KTSP) 2006 menyangkut pelajaran bahasa Indonesia bahwa fungsi utama bahasa adalah salah satu alat komunikasi untuk mengemukakan pendapat/gagasan. Berbahasa merupakan wujud sifat manusia sebagai makhluk yang selalu ingin berinteraksi dengan orang lain. Di saat manusia ingin menyapa atau menyampaikan maksud kepada orang lain, maka bahasalah yang digunakan sebagai medianya. Namun dari aktivitas kebahasan tersebut yang sangat ditekankan adalah keterampilan seseorang berbahasa, sebab bahasa akan lebih mudah dipahami jika disampaikan dengan yang terampil dalam berbahasa. Salah satu keterampilan berbahasa adalah berbicara.

Depdiknas (2005:184) dijelaskan bahwa berbicara adalah berkata, bercakap, berbahasa atau melahirkan pendapat (dengan perkataan, tulisan, dsb.) atau berunding. Pentingnya fungsi bahasa sebagai alat komunikasi dan alat berpikir terlihat pada mata pelajaran Bahasa Indonesia yang diberikan mulai dari pendidikan dasar sampai perguruan tinggi. Pada saat ini masih banyak siswa yang tidak terampil dalam berbicara karena rasa takut, apabila yang dikatakannya salah atau mengatakan hal yang benar dengan cara yang salah, kosa kata anak yang kurang dalam berbicara dan penggunaan metode pembelajaran yang kurang tepat pada kenyataannya guru hanya memakai metode ceramah dalam kegiatan belajar mengajar bahkan guru tidak mengajarkan berbicara yang baik sehingga membuat anak menjadi bosan dan setiap harapan tidak sesuai dengan kenyataan persoalan inilah yang terjadi pada siswa kelas III SD Negeri 060954 Medan. Hal ini dapat dilihat dari masih banyaknya siswa yang belum mampu untuk berbicara pada hasil persentase pengamatan.

\section{Tabel 1.1: Persentase Pengamatan SD Negeri 060954 Medan.}




\section{NIZHAMIYAH}

JurnalPendidikanIslamdanTeknologiPendidikan

Vol. VIII,No1,Januari- Juni 2018

ISSN2086-4205

\begin{tabular}{|c|c|c|}
\hline Nilai & Jumlah Siswa & Persentase \\
\hline$\geq 75$ & 10 & $41,67 \%$ \\
\hline$\leq 75$ & 14 & $58,33 \%$ \\
\hline Jumlah & 24 & $100 \%$ \\
\hline
\end{tabular}

Dari 24 jumlah siswa yang di kelas IIISD Negeri 060954 Medan, hanya 10 siswa $(41,67 \%)$

yang mampu berbicara dengan baik dalam Bahasa Indonesia. Sedangkan 14 siswa lagi (58,33\%)

masih belum mampu berbicara dengan baik dalam Bahasa Indonesia.

Keterampilan siswa berkomunikasi sebagai makhluk sosial hanya dapat dikembangkan dalam kebersamaan dengan sesamanya. Melalui kebersamaan itulah seorang siswa mengenal dan membentuk dirinya. Buah pikirannya diuji dalam pikiran orang lain melalui keterampilannya berbicara. Keterampilan berbicara perlu guna peningkatan kemampuan intelektual, emosional, sosial. Manusia Indonesia saat ini ketika diminta berbicara malah diam, sebaliknya ketika di minta diam malah ribut berbicara dengan teman yang berada di dekatnya. Dengan meningkatkan kemampuan mengemukakan pendapat secara lisan diharapkan siswa dapat memahami dan memecahkan berbagai persoalan yang berhubungan dengan evaluasi dari mata pelajaran Bahasa Indonesia yang diperolehnya di sekolah.

Minat belajar siswa yang masih rendah dalam berbicara mempengaruhi kemampuan siswa dalam materi ini menjadikan siswa malas dan cenderung bosan. Hal ini sangat berpengaruh dalam proses pembelajaran, terutama didalam pembelajaran berbicara. Melihat kondisi demikian, maka perlu adanya pembelajaran yang berorientasi pada bagaimana siswa belajar menemukan sendiri informasi, menghubungkan topik yang sudah dipelajari dan yang akan dipelajari dalam kehidupan sehari-hari, serta dapat berinteraksi multi arah baik bersama guru maupun bersama siswa selama siswa dalam suasana yang menyenangkan dan bersahabat. Salah satu alternatif yang digunakan adalah pembelajaran kooperatif tipe teknik berpasangan.

Melalui pembelajaran ini siswa bersama kelompok saling membantu antara teman yang satu dengan yang lain dalam kelompok tersebut sehingga percakapan berjalan dengan baik. Tipe bercerita berpasangan merupakan salah satu tipe kooperatif. Teknik bercerita berpasangan bisa digunakan untuk semua tingkatan usia anak didik. 


\section{NIZHAMIYAH}

JurnalPendidikanIslamdanTeknologiPendidikan

Vol. VIII,No1,Januari- Juni 2018

\section{ISSN2086-4205}

Berdasarkan latar belakang di atas, penulis merasa tertarik untuk melakukan penelitian yang berjudul "Upaya Meningkatkan Kemampuan Berbicara Siswa Melalui Teknik Bercerita Berpasangan di Kelas III SD Negeri 060954 Medan”.

\section{B. KERANGKA TEORITIS}

\section{Keterampilan Berbicara}

Linguis dalam Henry Guntur Tarigan (1981:3) menyatakan bahwa "speaking is language". Berbicara adalah suatu keterampilan berbahasa yang berkembang pada kehidupan anak, yang hanya didahului oleh keterampilan menyimak, dan pada masa tersebutlah kemampuan berbicara atau berujar dipelajari.

Kegiatan berbicara dapat efektif, apabila pembicara menguasai bahasa yang sama-sama dikuasai oleh penyimak. Pembicara harus mampu mengungkan gagasan, perasaan, dan kehendaknya dalam bahasa ujaran yang efektif. Untuk itu diperlukan kemampuan linguistic yang berupa bentuk bentuk fonologis, morfologi, sintaksis, diksi, serta kemampuan nonlinguistik yang berupa mimik dan unsur kinesik yang lain dapat menunjang keefektifan pembicara.

Mulyati, dkk. (2007:11) menyatakan situasi keterampilan berbicara ada tiga macam, yaitu:

a. Keterampilan Berbicara Interaktif

b. Keterampilan Berbicara Semiinteraktif

c. Keterampilan Berbicara Noninteraktif

2. Teknik Bercerita Berpasangan

Teknik mengajar bercerita berpasangan (Paired Storytelling) dikembangkan sebagai pendekatan interaktif antara siswa, pengajar, dan bahan pelajaran (Lie, 1994). Teknik ini bisa digunakan dalam pengajaran membaca, menulis, mendengarkan, ataupun berbicara.Pendekatan ini bisa pula digunakan dalam beberapa mata pelajaran, seperti ilmu pengetahuan sosial, agama, dan bahasa. Bahan pelajaran yang paling cocok digunakan dengan teknik ini adalah bahan yang bersifat naratif dan deskriptif. Namun, hal ini tidak menutup kemungkinan dipakainya bahanbahan yang laiinnya. 


\section{HASIL PENELITIAN}

1. Ketuntasan Hasil Belajar Siswa Siklus I

Pada pelaksanaan pembelajaran Siklus I peneliti bertindak sebagai guru yang diobservasi, mulai dari awal pelaksanaan tindakan sampai selesainya tindakan berupa pengajaran dengan menggunakan teknik bercerita berpasangan pada pokok bahasan peristiwa Kelas III SD Negeri 060954 Medan untuk meningkatkan kemampuan berbicara siswa.

a. Ketuntasan Hasil Belajar Siswa Secara Individual

Hasil dari penelitian tindakan kelas pada Siklus I pada mata pelajaran Bahasa Indonesia dengan pokok bahasan peristiwa dengan menggunakan teknik bercerita berpasangan, diperoleh data ketuntasan belajar siswa secara individual. Dibawah ini akan diuraikan data ketuntasan belajar siswa secara individual pada Tabel 1.2.

Tabel 1.2Ketuntasan Hasil Belajar Siswa Secara Individual Siklus I

\begin{tabular}{|l|l|c|c|c|}
\hline \multirow{2}{*}{ No } & \multicolumn{4}{|c|}{ Indikator Penilaian Pada Siswa Bercerita Berpasangan } \\
\cline { 2 - 5 } & Nomor Subjek & KKM & Nilai & Keterangan \\
\hline $\mathbf{1}$ & 01 & 75 & 66 & Tidak Tuntas \\
\hline $\mathbf{2}$ & 02 & 75 & 76 & Tuntas \\
\hline $\mathbf{3}$ & 03 & 75 & 80 & Tuntas \\
\hline $\mathbf{4}$ & 04 & 75 & 56 & Tidak Tuntas \\
\hline $\mathbf{5}$ & 05 & 75 & 30 & Tidak Tuntas \\
\hline $\mathbf{6}$ & 06 & 75 & 62 & Tidak Tuntas \\
\hline $\mathbf{7}$ & 07 & 75 & 64 & Tidak Tuntas \\
\hline $\mathbf{8}$ & 08 & 75 & 72 & Tidak Tuntas \\
\hline $\mathbf{9}$ & 09 & 75 & 46 & Tidak Tuntas \\
\hline $\mathbf{1 0}$ & 10 & 75 & 52 & Tuntas \\
\hline $\mathbf{1 1}$ & 11 & 75 & 80 & Tuntas \\
\hline $\mathbf{1 2}$ & 12 & 75 & 88 & Tidak Tuntas \\
\hline $\mathbf{1 3}$ & 13 & 75 & 78 & Tuntas \\
\hline $\mathbf{1 4}$ & 14 & & & \\
\hline
\end{tabular}




\begin{tabular}{|l|l|l|l|l|}
\hline $\mathbf{1 5}$ & 15 & 75 & 76 & Tuntas \\
\hline $\mathbf{1 6}$ & 16 & 75 & 84 & Tuntas \\
\hline $\mathbf{1 7}$ & 17 & 75 & 78 & Tuntas \\
\hline $\mathbf{1 8}$ & 18 & 75 & 78 & Tuntas \\
\hline $\mathbf{1 9}$ & 19 & 75 & 80 & Tuntas \\
\hline $\mathbf{2 0}$ & 20 & 75 & 80 & Tuntas \\
\hline $\mathbf{2 1}$ & 21 & 75 & 84 & Tuntas \\
\hline $\mathbf{2 2}$ & 22 & 75 & 72 & Tidak Tuntas \\
\hline $\mathbf{2 3}$ & 23 & 75 & 76 & Tuntas \\
\hline $\mathbf{2 4}$ & 24 & 75 & 70 & Tidak Tuntas \\
\hline
\end{tabular}

Dari table 1.2diuraikan data ketuntasan belajar siswa secara individual, diketahui 24 siswa yang ikut pada tes penilaian Siklus I masih tergolong rendah dengan dengan jumlah siswa yang tuntas sebanyak 13 orang dan jumlah siswa yang belum tuntas sebanyak 11 orang. kriteria ketuntasan secara individual dapat dilihat dari nilai yang ditetapkan pada nilai KKM, yaitu dengan sekor nilai 75 .

b. Hasil Belajar Siswa Secara Klasikal Siklus I

Setelah diketahui ketuntasan individu, selanjutnya diketahui hasil ketuntasan secara klasikal yang dirangkum dari tabel 1.3.

Tabel 1.3 Deskripsi Ketuntasan Belajar Siswa Secara Klasikal Siklus I

\begin{tabular}{|c|c|c|}
\hline \multirow{2}{*}{ Keterangan } & \multicolumn{2}{|c|}{ Siklus I } \\
\cline { 2 - 3 } & Hasil & Persentase \\
\hline Jumlah siswa yang tuntas belajar & 13 & $54,16 \%$ \\
\hline Jumlah siswa yang belum tuntas belajar & 11 & $45,83 \%$ \\
\hline Jumlah siswa & 24 & $100 \%$ \\
\hline
\end{tabular}

Dari Tabel 1.3 di atas, dapat dilihat perolehan sebesar 54,16\% siswa yang telah dinyatakan tuntas belajar dan siswa yang dinyatakan belum tuntas sebesar $45,83 \%$. Hasil yang diperoleh siswa belum dapat dikatakan tuntas secara klasikal,secara klasikal dapat dinyatakan tuntas belajar bila persentase ketuntasan siswa dalam satu kelas mencapai $85 \%$ sesuai kriteria nilai KKM. 


\section{NIZHAMIYAH}

JurnalPendidikanIslamdanTeknologiPendidikan

Vol. VIII,No1,Januari- Juni 2018

ISSN2086-4205

Perolehan nilai dan persentase ketuntasan siswa secara klasikal pada siklus I sebesar $54,16 \%$, yang berarti secara klasikal belum dapat dinyatakan tuntas. Oleh karena itu, maka peneliti menganggap perlu diadakanya siklus II, guna memaksimalkan upaya peneliti dalam meningkatkan ketuntasan secara individual dan klasikal.

2. Ketuntasan Hasil Belajar Siswa Siklus II

Pada penelitian Siklus II ini peneliti berusaha semaksimal mungkin untuk memperbaiki kekurangan-kekurangan pada Siklus I.Pengamatan yang dilakukan oleh guru bidang study Bahasa Indonesia di dalam kelas selama proses penelitian berlanjut, dimana guru bidang study melihat dan menilai setiap tindakan yang dilakukan guru peneliti dalam pengajaran dengan menggunakan teknik bercerita berpasangan

a. Ketuntasan Hasil Belajar Siswa Secara Individual

Hasil dari penelitian tindakan kelas pada Siklus II pada mata pelajaran Bahasa Indonesia dengan pokok bahasan peristiwa dengan menggunakan teknik bercerita berpasangan, diperoleh data ketuntasan belajar siswa secara individual. disimpulkan bahwa hasil belajar telah meningkat. Dari 24 siswa, sebanyak 21 siswa telah memenuhi kriteria ketuntasan belajar yang telah ditetapkan, sedangkan yang tidak tuntas sebanyak 3 siswa maka penelitian tidak perlu dilanjutkan ke Siklus berikutnya.

Tabel 1.4 Ketuntasan Hasil Belajar Siswa Secara Individual Siklus II

\begin{tabular}{|c|c|c|c|c|}
\hline \multirow{2}{*}{ No } & \multicolumn{4}{|c|}{ Indikator Penilaian Pada Siswa Bercerita Berpasangan } \\
\cline { 2 - 5 } & Nomor Subjek & KKM & Nilai & Keterangan \\
\hline 1 & 01 & 75 & 76 & Tuntas \\
\hline 2 & 02 & 75 & 82 & Tuntas \\
\hline 3 & 03 & 75 & 88 & Tuntas \\
\hline 4 & 04 & 75 & 80 & Tidak Tuntas \\
\hline 5 & 05 & 75 & 56 & Tidak Tuntas \\
\hline 6 & 06 & 75 & 72 & Tuntas \\
\hline 7 & 07 & 75 & 76 & \\
\hline
\end{tabular}




\begin{tabular}{|c|l|l|l|l|}
\hline 8 & 08 & 75 & 76 & Tuntas \\
\hline 9 & 09 & 75 & 66 & Tidak Tuntas \\
\hline 10 & 10 & 75 & 76 & Tuntas \\
\hline 11 & 11 & 75 & 80 & Tuntas \\
\hline 12 & 12 & 75 & 90 & Tuntas \\
\hline 13 & 13 & 75 & 78 & Tuntas \\
\hline 14 & 14 & 75 & 86 & Tuntas \\
\hline 15 & 15 & 75 & 86 & Tuntas \\
\hline 16 & 16 & 75 & 88 & Tuntas \\
\hline 17 & 17 & 75 & 86 & Tuntas \\
\hline 18 & 18 & 75 & 78 & Tuntas \\
\hline 19 & 19 & 75 & 86 & Tuntas \\
\hline 20 & 20 & 75 & 86 & Tuntas \\
\hline 21 & 21 & 75 & 88 & Tuntas \\
\hline 22 & 22 & 75 & 78 & Tuntas \\
\hline 23 & 23 & 75 & 78 & Tuntas \\
\hline 24 & 24 & 75 & 86 & Tuntas \\
\hline
\end{tabular}

Berdasarkan Tabel 1.4, dapat dilihat bahwa hasil belajar yang diperoleh siswa telah meningkat.Sebanyak 21 siswa telah memenuhi kriteria ketuntasan belajar (KKM), sedangkan yang tidak tuntas sebanyak 3 siswa. Ketuntasan dilihat dari KKM yang telah di tetapkan sebesar 75.

\section{b. Hasil Belajar Siswa Secara Klasikal Siklus II}

Setelah diketahui ketuntasan individual, selanjutnya ketuntasn secara klasikal yang dirangkum dari hasil belajar siswa pada siklus II. Pada Siklus II hasil belajar siswa yang tuntas adalah 21 siswa dari 24 siswa. Secara klasikal hasil belajar siswa telah mencapai 87,5\% sehingga dapat disimpulkan bahwa pada Siklus II ketuntasan belajar siswa mengalami peningkatan dibandingkan Siklus I dan tuntas secara klasikal.

Berdasarkan hasil pengamatan pembelajaran pada Siklus II dapat diketahui bahwa peneliti sudah mengupayakan perbaikan proses pembelajaran di dalam kelas, sehingga terlihat 


\section{NIZHAMIYAH}

JurnalPendidikanIslamdanTeknologiPendidikan

Vol. VIII,No1,Januari- Juni 2018

ISSN2086-4205

adanya perubahan hasil belajar siswa dari Siklus I. pada siklus II sebanyak 21 siswa yang tuntas atau mencapai 87,5\%. Untuk lebih jelas dapat dilihat pada tebal 1.5.

Tabel 1.5 Deskripsi Ketuntasan Belajar Siswa Secara Klasikal Siklus II

\begin{tabular}{|l|c|c|}
\hline \multirow{2}{*}{$\begin{array}{c}\text { Keterangan } \\
\text { Berdasarkan data penelitian, maka hipotesis yapmasiajukan yang bperłevitàse'Dengan }\end{array}$} & \multicolumn{2}{|c|}{ Siklus II } \\
\cline { 2 - 3 } & 21 & $87,5 \%$ \\
\hline Jumlah siswa yang tuntas & 3 & $12,5 \%$ \\
\hline Jumlah siswa yang belum tuntas & 24 & $100 \%$ \\
\hline
\end{tabular}

Dari Tabel 1.5 di atas, dapat dilihat perolehan sebesar 87,5\% siswa yang telah dinyatakan tuntas belajar dan siswa yang dinyatakan belum tuntas sebesar 12,5\%. Hasil yang diperoleh siswa dapat dikatakan tuntas secara klasikal,secara klasikal dapat dinyatakan tuntas belajar bila persentase ketuntasan siswa dalam satu kelas mencapai 85\% sesuai kriteria nilai KKM.Dengan demikian, dapat dinyatakan bahwa hasil keterampilan berbicara siswa meningkat dengan menggunakan teknik bercerita berpasangan.

\section{KESIMPULAN DAN SARAN}

\section{A. Simpulan}

Berdasarkan hasil pelaksanaan penelitian tindakan kelas siswa Kelas III SD Negeri 060954 Medan dapat disimpulkan sebagai berikut:

1. Pelaksanaan pembelajaran dengan menggunakan teknik bercerita berpasangan pada mata pelajaran Bahasa Indonesia di kelas III SD Negeri 060954 Medan telah mencapai kategori baik.

2. Hasil belajar siswa dengan menggunakan teknik bercerita berpasangan di kelas III SD Negeri 060954 Medan telah meningkat dengan ketuntasan klasikal $\geq 85 \%$.

\section{B. Saran}

Berdasarkan hasil penelitian dan kesimpulan-kesimpulan di atas, maka sebagai tindak lanjut peneliti menyarankan:

1. Guru hendaknya menggunakan teknik bercerita berpasangan, supaya siswa aktif, kreatif dalam berbicara. 


\section{NIZHAMIYAH}

JurnalPendidikanIslamdanTeknologiPendidikan

Vol. VIII,No1,Januari- Juni 2018

\section{ISSN2086-4205}

2. Kepala sekolah mengimbau dan melatih guru-guru untuk terampil mengggunakan teknik bercerita berpasangan dalam mengajarkan keterampilan berbicara.

3. Disarankan guru melakukan pendekatan khusus secara individual terhadap siswa yang belum mengalami peningkatan berbicara

4. Hendaknya guru menanamkan kesadaran, kerjasama, saling menghargai pendapat teman, kedisiplinan kepada siswa agar tercipta suasana yang aman dan tentram dalam proses belajar mengajar.

\section{DAFTAR PUSTAKA}

Abdurrahman, Mulyono. 2012. “Anak Berkesulitan Belajar. Jakarta: Rineka Cipta.

Arikunto, Suharsimi, dkk. 2012. “Penelitian Tindakan Kelas”. Jakarta: PT. Bumi Aksara.

Aqib, Zainal, dkk. 2010. "Penelitian Tindakan Kelas”. Bandung: CV YramaWidya.

Darmadi Kaswan dan Nirbaya Rita. 2008. ” Bahasa Indonesia Untuk SD dan MI

Kelas III”. Jakarta: Pusat Perbukuan, Departemen Pendidikan Nasional.

Dimyati dan Mudjiono. 2013. “Belajar dan Pembelajaran”. Jakarta: PT Rineka Cipta.

Hidayat, dkk. 1994. "Evaluasi Pendidikan dan Penerapannya dalam Pembelajaran

Bahasa Indonesia”. Bandung: Alfabeta.

Istarani. 2011. “58 Model Pembelajaran Inovatif”. Medan: Media Persada.

Jihad Asep dan Haris Abdul, 2012. "Evaluasi Pembelajaran”. Yogyakarta: Multi Pressiondo.

Lie, Anita. 2010. “Cooperatif Learning”. Jakarta: Grasindo.

Ngalimun dan Alfulaila Noor. 2013. “Pembelajaran Keterampilan Berbahasa Indonesia”. Yogyakarta: Aswaja Pressindo.

Sahertian, Piet A. 2008. "Konsep Dasar \& Teknik Supervisi Pendidikan Dalam Rangka Pengembangan Sumber Daya Manusia”. Jakarta: PT Rineka Cipta

Slameto. 2010. “Belajar dan Faktor-Faktor Yang Mempengaruhi”. Jakarta: PT. Rineka Cipta.

Syah, Muhibbin. 2010. “Psikologi Pendidikan”. Bandung: PT. Remaja Rosdakarya.

Tantawi, Isma. 2014. "Bahasa Indonesia Akademik. Bandung: Citapustaka Media.

Tarigan. 2007. “Berbicara Sebagai Suatu Keterampilan Berbahasa”. Bandung: Angkasa.

Trianto. 2009. Mendesain Model Pembelajaran Inovatif-Progresif. Jakarta: Kencana. 


\section{NIZHAMIYAH}

JurnalPendidikanIslamdanTeknologiPendidikan

Vol. VIII,No1,Januari- Juni 2018

ISSN2086-4205 